ENTREPRENEURSHIP AND SUSTAINABILITY ISSUES

ISSN 2345-0282 (online) http://jssidoi.org/jesi/

2021 Volume 8 Number 3 (March)

http://doi.org/10.9770/jesi.2021.8.3(34)
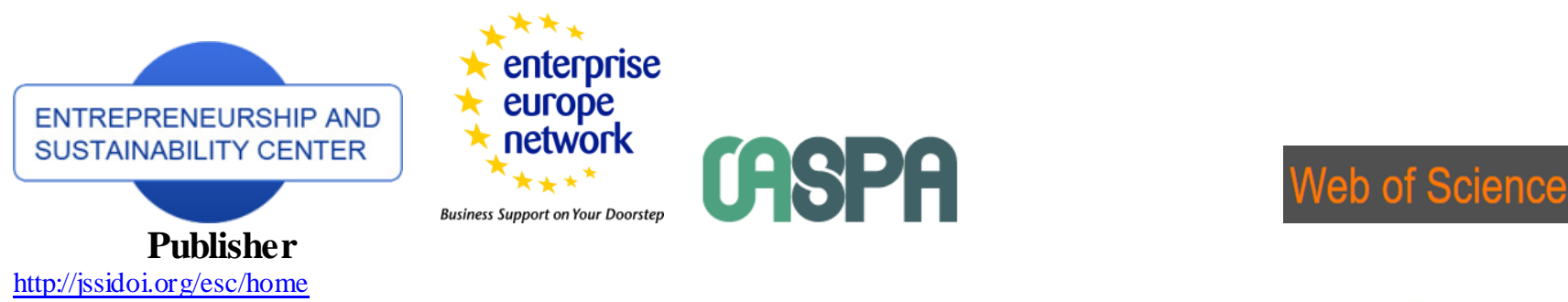

$\underline{\mathrm{http}: / / \text { issidoi.org/esc/home }}$

Business Support on Your Doorstep

1) Clarivate

Analytics

\title{
DIRECT SUBSIDIES AND COMPENSATION FUNDS IN FINANCING OF UNIVERSAL POSTAL SERVICES
}

\author{
Leszek Borowiec
}

University of Economics and Human Sciences in Warsaw, Okopowa 59, 01 -043 Warsaw, Poland

E-mails: l.borowiec@vizja.pl

Received 9 April 2020; accepted 31 January 2021; published 30 March 2021

\begin{abstract}
Member States of the European Union are obliged to ensure access to universal postal services for all citizens. The aim of the study is to assess the effectiveness of direct subsidies and compensation funds as basic methods of financing universal postal services in the scope of incurred net cost on the example of selected postal operators in Europe and to indicate the results of application of such solutions. The scope of the study includes an evaluation of the direct subsidy mechanism applicable in Europe on the example of Belgium. A characterization of the legal framework of operation of the compensation fund and an analysis of the impact of the adopted financing mechanisms on the achieved level of profitability of the entity obliged to provide universal postal services in Poland were made. The thesis of the current study is that the mechanism of compensation for provision of universal postal services by means of a compensation fund on the Polish example is defective and ineffective from the point of view of market regulation and the designated postal operator. The study concludes by stating that the preferred form of net cost financing should be a full budget subsidy and that it is unjustified to charge the full value of the net cost as additional commitment to the operator. The research methods used include analysis of scientific literature, collection, comparison, classification and generalization of data and expert evaluation.
\end{abstract}

Keywords: postal sector; net cost of universal service; loss on universal service; direct subsidies; compensation fund; unfair financial burden

Reference to this paper should be made as follows: Borowi8ec, L. 2021. Direct subsidies and compensation funds in financing of universal postal services. Entrepreneurship and Sustainability Issues, 8(3), 545-564. http://doi.org/10.9770/jesi.2021.8.3(34)

JEL Classifications: G38, D43, L51

\section{Introduction}

Universal postal services are considered services of general economic*interest (SGEI), that is, their provision is in the public interest (they implement public service mission). They are entities which would not be provided otherwise (or would be provided under less favorable conditions) on the market without public intervention

\footnotetext{
* According to point 12 of the 2012 SGEI framework agreements, subsidies may be granted for an actual and correctly defined service of general economic interest (EU Treaty 2002, art. 106).
} 
because the postal operator would consider them unprofitable (Commission Communication, 2011). Public intervention usually involves imposing obligations on a particular enterprise to ensure access to services of general economic interest for all citizens at affordable prices and of specified quality.

The operator designated to perform the obligations included in the scope of universal postal services shall bear the costs related to the obligations imposed on it independently, which may negatively influence its financial performance. The calculation of the net cost is intended to determine whether the designated operator's financial performance is affected by the obligations imposed. In the case of a positive net cost value, a significant problem arises as to how the additional costs should be compensated for by the operator designated in the universal service sector in order not to impair its market position in fully commercial service areas, without using prohibited public aid which distorts market mechanisms. According to the 3rd Postal Directive (Directive, 2008), application of any financing mechanism currently depends on fulfilling the following conditions: (1) universal service obligations entail a net cost for the operator responsible for providing the universal service, (2) the net cost represents an unjustified financial burden for that operator.

The article analyses alternative ways of financing the universal service obligation. Although there is no single model mechanism for universal service obligation financing, it may be possible to combine several alternatives to ensure that the postal service has sufficient revenue to cover the costs of universal service provision. In addition to the forms of universal service financing listed in Table 1, such as direct subsidies or compensation funds, in practice (Accenture, 2015), a diversification method that allows postal operators to develop other areas of activity that will financially support their core postal activities can still be applied. Moreover, on monopolistic markets, price regulation of postal services may be considered to ensure that the requirements of the universal service are met.

Table 1. Possible forms of universal service provision financing

\begin{tabular}{|c|c|c|}
\hline Form of financing & $\begin{array}{c}\text { Description } \\
\end{array}$ & Assessment \\
\hline $\begin{array}{c}\text { Direct } \\
\text { subsidies }\end{array}$ & $\begin{array}{l}\text { This includes all direct funding made by the } \\
\text { government to cover the cost of commitments. } \\
\text { For foreign postal services, payments are } \\
\text { targeted to specific obligations. }\end{array}$ & $\begin{array}{l}\text { The most appropriate funding mechanism for European } \\
\text { postal services. It has relatively low administrative costs. } \\
\text { Policy makers are responsible for both the definition of } \\
\text { USO levels and their financing. }\end{array}$ \\
\hline Compensation fund & $\begin{array}{l}\text { A fund used to compensate for the cost of } \\
\text { universal service obligations. The fund is paid by } \\
\text { other service providers or customers. }\end{array}$ & $\begin{array}{c}\text { Administering funding processes is costly and complicated. } \\
\text { Raising sufficient funds is unlikely, as the dominant } \\
\text { operators will co-finance USOs. }\end{array}$ \\
\hline $\begin{array}{c}\text { Universal service } \\
\text { contracts }\end{array}$ & $\begin{array}{l}\text { USO elements are publicly auctioned; the } \\
\text { winning operator receives a minimum subsidy to } \\
\text { provide the service. }\end{array}$ & $\begin{array}{l}\text { The method is not practiced. In a market with a dominant } \\
\text { position it is difficult to ensure competitiveness in } \\
\text { individual orders. }\end{array}$ \\
\hline $\begin{array}{l}\text { State liability for } \\
\text { irreversible costs }\end{array}$ & $\begin{array}{c}\text { It is not a direct financing mechanism. It consists } \\
\text { of the state taking responsibility for costs which } \\
\text { were incurred when the operator was a state } \\
\text { institution. }\end{array}$ & $\begin{array}{l}\text { This is temporary instrument to compensate for excessive } \\
\text { labor costs during privatization. The disadvantage is the } \\
\text { lack of transparency of settlements. }\end{array}$ \\
\hline
\end{tabular}

Source: Own elaboration based on Dieke, Junk (2015b)

As the analysis carried out in Table 1 proves that two methods have the potential to fulfil an appropriate role in universal postal services financing. These include central funding in the form of direct subsidies or compensation funds. In the current study, they will be analyzed using selected national operators in the EU as examples, with particular reference to the period of implementation of these solutions in each country. A multi-year perspective regarding the functioning of the solutions provides a more complete view that allows to conclude on the effectiveness of the applied solutions and the possibilities of their development in the postal and related industries (telecommunications, media, transport services, etc.). The remaining forms of financing described in Table 2 have 
only some of the characteristics desired for the mechanism of universal services financing and may be an attempt to improve the financial situation of operators rather than the system itself.

\section{Literature review}

In order to correctly estimate potential additional costs of the universal postal service obligation, it is necessary to determine the net cost of these services incurred by the designated operator. In theory, the determination of the net cost of universal service obligations is relatively simple - it is the difference between the net cost of a designated universal service provider covered by universal service obligations and that of a non-universal service provider. This definition of net cost of the universal service obligation was introduced in 2008 by the 3rd Postal Directive, which is relatively late. In earlier studies, the concept of net cost was also used, but it was not necessarily the same as the concept of net cost of the universal service obligation within the meaning of the 3rd Postal Directive.

The available studies on the determination of the net cost of universal service obligations distinguish three main methodologies for the calculation of net cost, with modifications (Dietl, Grütter, Lutzenberger, 2001): 1) Net Avoidable Cost (NAC) 2) Entry Pricing (EP); 3) Profitability Cost (PC) Each of the methodologies presented in Figure 1 takes a different approach to net cost calculation and assumes a different market situation of the postal operator. In the currently available studies, it is possible to find the Commercial Approach (CA) methodology, which in Figure 1 would be in PC's place. According to the author, the approach to estimating of the net cost of universal service obligations according to the CA method is not a separate methodology, but only a more detailed and developed version of the PC method.

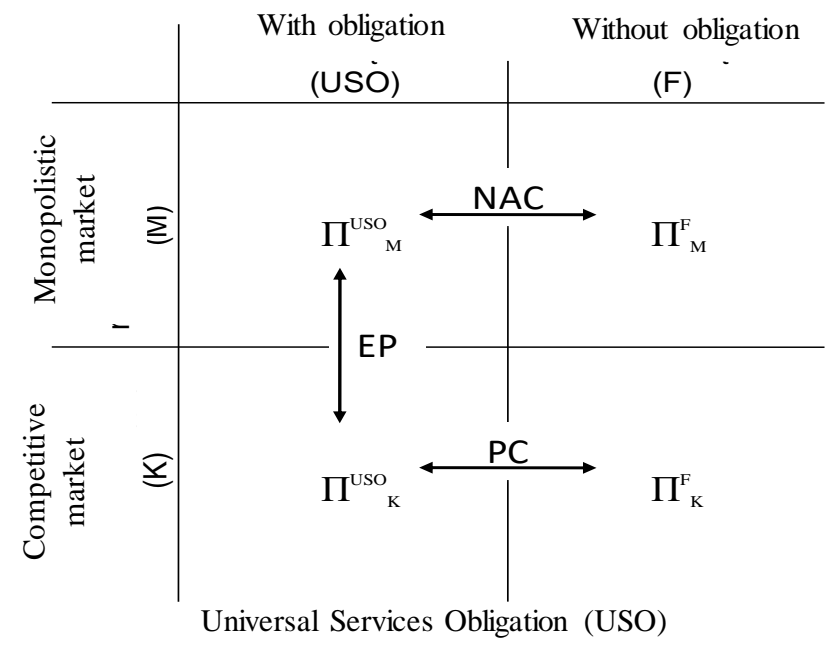

Fig. 1. Links between methodologies of universal service obligations net cost calculation

Source: Dietl (2001)

NAC (Net Avoidable Cost) methodology (OFTEL, 1995; NERA, 1998) may be used to calculate the additional costs to be borne by the designated operator as a result of universal service obligations on a monopolistic market. According to the NAC methodology, calculation of the universal service obligation net cost consists in estimating the cost of those postal services which are obligatory for universal services, and would not be provided without the obligation to do so. In European Union countries, the NAC methodology was used in the UK in 2001 by the consultancy firm Andersen, commissioned by the UK market regulator Postcomm (Postcomm, 2001). 
ENTREPRENEURSHIP AND SUSTAINABILITY ISSUES

ISSN 2345-0282 (online) http://jssidoi.org/jesi/

2021 Volume 8 Number 3 (March)

http://doi.org/10.9770/jesi.2021.8.3(34)

Entry Pricing (PwC 1998; Rodriguez, \& Storer, 2000) can be used to calculate the additional costs of universal service obligations to be borne by the operator designated in the process of market liberalization. In European Union countries, the EP methodology was used in Belgium in 2009 by the consultancy firm KPMG, commissioned by the Belgian market regulator BIPT (Belgian Institute for Postal Service And Telecommunications) for the Belgian operator (KPMG, 2009).

Profitability Cost methodology (Panzar, 2000; Cremer, Grimaud, \& Laffont, 2000) may be used to calculate the additional costs to be borne by an operator designated as a result of universal service obligations in a competitive market. Examples of practical application of PC can be found in many European Union countries, including Poland, Great Britain or Denmark (Frontier Economics, 2008; Copenhagen Economics, 2008). In some studies, the aforementioned methodology is also referred to as NAC methodology for a competitive market.

In calculating the net cost of universal service obligations, the CA (Commercial Approach) is also mentioned. It is included in the CERP (Comité Européen des Régulateurs Postaux) and in a document on USO cost calculation in Denmark (Copenhagen Economics, 2008). The authors state that it can be described as PC method with a broader perspective because: 1) it assumes that the operator is to a large extent dependent on senders; 2) it considers the effects demand and substitution when comparing alternative options; 3) it considers weighted average cost of capital (WACC) when calculating the net cost of services; 4) estimates the costs avoided in the absence of the USO obligation; 5) it compares avoidable costs with revenue that would be lost in the event of discontinuation or change in the way postal services are provided.

It should be noted that none of the above elements are excluded from being included in the PC methodology, where all possible aspects of a postal operator's activity in a competitive market have to be considered, which also includes demand and substitution effects. In this light, the CA approach is only a detailed version of the existing PC methodology and, as a rule, both the PC methodology and the CA approach are correct and comply with the provisions of the 3rd Postal Directive (Directive, 2008). The correct application of the PC methodology, including all the requirements imposed by the Directive, does not make a substantive difference between the net cost value of USO obtained using the PC methodology and the CA approach.

Table 2. Review of practices and use of methods for calculating the cost of universal service obligations

\begin{tabular}{|c|c|c|c|c|}
\hline Methodology & Scope of application & Practice & Indirect benefits & Comments \\
\hline NAC & $\begin{array}{c}\text { Cost of USO on a } \\
\text { monopolistic market }\end{array}$ & $\begin{array}{c}\text { Great Britain } \\
(2001)\end{array}$ & $\begin{array}{c}\text { Reported } \\
\text { not assessed } \\
\text { Does not meet the } \\
\text { requirements of the 3rd } \\
\text { Postal Directive }\end{array}$ \\
\hline EP & $\begin{array}{c}\text { Cost of USO in market } \\
\text { liberalization }\end{array}$ & $\begin{array}{c}\text { Belgium } \\
(2009)\end{array}$ & $\begin{array}{c}\text { Reported } \\
\text { not assessed } \\
\text { requirements of the 3rd } \\
\text { Postal Directive }\end{array}$ \\
\hline PC & $\begin{array}{c}\text { Net cost of USO in an } \\
\text { open market with and } \\
\text { without USO }\end{array}$ & $\begin{array}{c}\text { United Kingdom } \\
(2008) \\
\text { Denmark (2008) }\end{array}$ & $\begin{array}{c}\text { Not included } \\
\text { Reported and assessed }\end{array}$ & $\begin{array}{c}\text { Meets the requirements of } \\
\text { the 3rd Postal Directive }\end{array}$ \\
\hline
\end{tabular}

Source: Own elaboration

As shown by European practice presented in Table 2, different methods for calculating the cost of universal service obligations have been applied in particular countries. It should be noted, however, that not every method can obtain the net cost within the meaning of the provisions of the 3rd Postal Directive (Directive, 2008). The described examples of NAC and EP do not meet the requirements of the Directive. This results directly from the assumptions of the methodologies used and confirms the conclusion that only the use of the PC methodology, 


\section{ENTREPRENEURSHIP AND SUSTAINABILITY ISSUES}

ISSN 2345-0282 (online) http://jssidoi.org/jesi/

2021 Volume 8 Number 3 (March)

http://doi.org/10.9770/jesi.2021.8.3(34)

which covers all effects on both the cost and revenue side, results in an estimate consistent with the definition of the net cost of universal service obligations.

For the financing mechanism to trigger, the following need to occur: the net cost of the universal service and an unjustified financial burden on the operator. As it was mentioned, the definition of net cost is included in the 3rd Postal Directive and the methodology is described precisely in the literature (e.g. Frontier Economics, 2008; Jaag, Koller, \& Trinkner, 2009; Jaag, 2011a). Most models of the universal postal service are exogenous, and scientific studies boil down to the analysis of their implementation in individual countries (see e.g.: Cohen, Mc Bride, \& Panzar, 2010; Bergum, 2008; Anton, VanderWeide, \& Vettas, 2002; Bourguignon, \& Ferrando, 2007; Calzada, 2009; Choné, Flochel, \& Perrot, 2002; Foros, \& Kind, 2003; Gautier, \& Mizuno, 2011; Gautier, \& Paolini, 2011; Gautier, \& Wauthy, 2010; Jaag, 2011; Borowiec 2012; Borowiec 2013; Rozbiecki, \& Rosiak, 2014; KPMG, 2010). However, the 3rd Postal Directive does not explain what the term "unjustified financial burden" entails (Borowiec, 2011). The literature (Boldron et al., 2009) often refers to situations where the burden exceeds a certain percentage of the designated operator's profits, prevents a 'reasonable profit' (Frontier Economics, 2012) or suggests to consider its financial situation (ERGP, 2012).

Issues related to the need to finance universal servic obligations are the subject of numerous studies as well (Boldron, Borsenberger, Joram et al., 2010; Borsenberger, Cremer, De Donder et al., 2010; Panzar 2008; Mirabel, Poudou, \& Roland, 2009; Chone, Flochel, \& Perrot, 2002). However, they serve classification and review purposes. They refer to the potential possibilities of introducing different financing instruments. There is no practical verification of the effectiveness of implemented mechanisms with the use of empirical data from individual markets in which universal postal service is provided, designated operators bear an unjustified burden and there is an implemented (operating) compensation mechanism for this. There is a lot of research into the impact of pricing policies in the market where universal service operator is present (Pardou, \& Roland, 2014; De Villemeur, Cremer, Roy, et al., 2003). Research often addresses theoretical issues in pricing and competition behavior mechanisms in imperfectly competitive markets (Anderson, De Palma, \& Kreider, 2001; Hoering, 2006; Armstrong, Doyle, \& Vickers, 1996; Bloch, \& Gautier, 2008; De Donder, 2006).

The latest research on operations of the postal services market, where universal services are provided, are focused on an attempt to redefine the scope. Analyzes are mainly undertaken in order to limit the most important components of the net cost, which directly affects the amount of unjustified burden on the operator, and therefore the amount of necessary compensation. This applies primarily to research on the availability of the postal network for customers and its impact on the quality of services provided (Mercier, Souche - Le Corvec, \& Ovtracht, 2020; Mostarac, Kavran, \& Rakic, 2019; Hostakova, 2018; Sarac, Unterberger, Jovanovic et al., 2017). There are also studies in which the postal network is examined from the point of view of the postal operator, in the framework of not necessarily an access for the customer, but of its profitability assessment and reorganization in order to increase its effectiveness (Blagojevic, Ralevic, \& Sarac, 2020; Milutinovic, Markovic, Stanivukovic, et al., 2020; Sarac, Kopic, Mostarac et al., 2016).

At the same time, it should be noted that new means of electronic communication and consumer needs undermine the economic justification and traditional scope of the postal universal service obligation (Lewandowski, Mlodkowski, \& Wrobel, 2019). In the future, individual countries will adapt their postal universal services to take into account the availability of electronic substitutes, changes in customer behavior and declining number of postal items, similar to the telecommunications market. Other areas of current research focus on comparing the efficiency of postal operators in EU countries (Ralević, Dobrodolac, \& Švadlenka, 2020), or in individual countries such as Ireland (Cahill, Palcic, Reeves et al., 2018) or Serbia (Dobrodolac, Blagojevic \& Draskovic, 2016; Dobrodolac, Ralević, Švadlenka, et al., 2018). Other areas of current research focus on comparing efficiency of postal operators in EU countries (Ralević, Dobrodolac, \& Švadlenka, 2020), or in individual 
ENTREPRENEURSHIP AND SUSTAINABILITY ISSUES

ISSN 2345-0282 (online) http://jssidoi.org/jesi/

2021 Volume 8 Number 3 (March)

http://doi.org/10.9770/jesi.2021.8.3(34)

countries such as Ireland (Cahill, Palcic, Reeves et al., 2018) or Serbia (Dobrodolac, Ralević, Švadlenka et al., 2018).

As indicated by the literature review, there is a research gap in the field of empirical verification of the application of individual instruments for financing the excessive burden on the universal service operator. If there are already studies based on the experience in implementing the universal postal service, they address problems with estimating costs or components of the universal service itself (e.g. network of post offices). This article fills this gap by presenting the advantages and disadvantages of the two basic financing arguments, which are the compensation fund and the direct subsidy, based on the experience of selected EU countries.

The aim of the current study is to assess the effectiveness of the direct subsidy and compensation fund as basic methods of financing universal postal services provided in the scope of incurred net cost on the example of postal operators in Europe and to determine the results of application of such solutions. The scope of the study includes an evaluation of the direct subsidy mechanism applicable in Europe on the example of Belgium. A characterization of the legal framework of operation of the compensation fund and an analysis of the impact of the adopted financing mechanisms on the achieved level of profitability of the entity obliged to provide universal postal services in Poland were made. The study also provides a brief overview of the solutions applied in other EU countries. The current study presents a thesis that the mechanism of compensation of the provision of universal postal services through compensation funds is defective and ineffective from the point of view of market regulation and the designated operator. The research problem also applies to other areas of public service provision, where a social need to provide universal services at the desired level exists (telecommunications, transport, media provision). Based on the aim and thesis of this paper, the following research questions were formulated:

1) what is the output of scientific literature in terms of the net cost of universal postal service, and in particular in relation to the use of compensation instruments for postal operators of unjustified burden,

2) what are the main advantages and limitations of using direct grants as a form of compensation, based on the example of Belgium,

3) how the compensation fund was implemented and operated in the process of granting compensation to the universal postal service operator, based on the example of Poland,

4) what are the directions of financial support for activities of postal operators in selected European countries,

5) what is the preferred form of effective support for universal postal service providers to achieve the objectives of the Third Postal Directive.

The research methods used include analysis of scientific literature, collection, comparison, classification and generalization of data and expert evaluation. In the study, the active research method was also used, as the author possesses extensive experience in the area of activity-based costing used by postal operators, among others, in estimating the net cost of universal services. The case study method was used to analyse the application of direct subsidies and the compensation fund in financing excessive burden on the designated operator of selected European countries. It is often used for research in the postal market, due to special circumstances of the activity of operators designated to provide universal postal services in individual countries.

\section{Direct Subsidies in Universal Postal Services on the example of Belgium}

The postal market in Belgium has been fully opened to competition since the beginning of 2011. Despite this, the competition is still small. Bpost is the designated postal operator in Belgium and provides universal and additional services resulting from the entrusted mission. TBC Post is their sole competitor. At the end of 2014, it was estimated that it shares less than $1 \%$ of the market in domestic postal services. The postal services market is regulated by BIPT. 
ENTREPRENEURSHIP AND SUSTAINABILITY ISSUES

ISSN 2345-0282 (online) http://jssidoi.org/jesi/

2021 Volume 8 Number 3 (March)

http://doi.org/10.9770/jesi.2021.8.3(34)

Table 3. Legal requirements of the universal postal service in Belgium

\begin{tabular}{|l|l|l|}
\hline \multicolumn{1}{|c|}{ Scope of services } & \multicolumn{1}{|c|}{ Timeliness } & \multicolumn{1}{c|}{ Delivery frequency } \\
\hline $\begin{array}{l}\text { National and international services: } \\
\bullet \quad \text { letters up to } 2 \mathrm{~kg}\end{array}$ & $\bullet \quad \begin{array}{l}\text { domestic letters: } 95 \%(\mathrm{~d}+1), 97 \%(\mathrm{~d}+2) \\
\text { - } \quad \begin{array}{l}\text { international letters: } \\
\text { registered and insured letters (no weight limit) }\end{array}\end{array}$ & 55\% days a week \\
$-\quad \begin{array}{l}\text { domestic parcels up to } 10 \mathrm{~kg} \\
\text { incoming parcels up to } 20 \mathrm{~kg}\end{array}$ & & \\
\hline
\end{tabular}

Source: Elaboration based on the Act (1991); Management Contract (2013)

Belgium is a country that offers a wide range of universal service benefits, as shown in Table 3 . All available postal services (except unaddressed advertisements) are part of the universal postal service. Unlike most European countries, legislation in Belgium provides additional public interest services in addition to the universal service. Table 4 presents the main bpost tasks, which go beyond the basic standard of universal service adopted in the EU.

Table 4. Additional public service objectives of bpost

\section{Postal network density (higher than re quired by USO)}

- The obligation to maintain retail outlets, at least 1300 postal service points and 650 post offices (more densely than required by USO, at least one post office in each of the 589 Belgian municipalities)

- Additionally, access to postal service points with a minimum range should be provided: for a minimum of $95 \%$ of residents $5 \mathrm{~km}$ away; for a minimum of $98 \%$ of residents $10 \mathrm{~km}$ away

Services offered to cons umers at a specific time (day after day service)

- Delivery of newspapers and magazines (delivery before 7:30 am during the week)

- Financial postal services (e.g. bank accounts)

- Pension delivery

Additional services available

- $\quad$ Postman social services (e.g. spending time with people living alone)

- Delivery of addressed/unaddressed electoral leaflets at reduced cost

- Delivery of correspondence sent by non-profit organizations at reduced prices

- Delivery of public institution mail, paid by the addressee

- $\quad$ Printing, promotion, return and replacement of fishing license

Source: Elaboration based on the Act (1991); Management Contract (2013)

In Belgium, postal law does not provide for the financing of postal services by means of compensation funds, although this was still possible until 2010. Currently, the net cost of the universal service and the cost of additional public services can only be compensated by public funds. The government has opted for direct subsidies from the budget due to the instability of other funding mechanisms such as the compensation fund, which has more procedures in place. It is also important that direct government funds have a neutral impact on competition.

For the calculation of the net cost, bpost should have a cost accounting system that clearly shows the differences between the various services falling within the scope of the universal service, public service missions and other postal services. The fully segregated cost method, to which Activity Based Costing (ABC) is applied, should be used for these estimates. For universal service, bpost must first calculate the net cost of universal service using the net avoidable cost method (the difference in operating result between the existing universal service obligation and its absence) and take into account other relevant elements, including indirect benefits. The net cost calculated this 
way must be verified by the BIPT. If the net cost of the universal service exceeds $3 \%$ of the universal service provider's trade turnover, this represents a reasonable burden which must be compensated by the central budget.

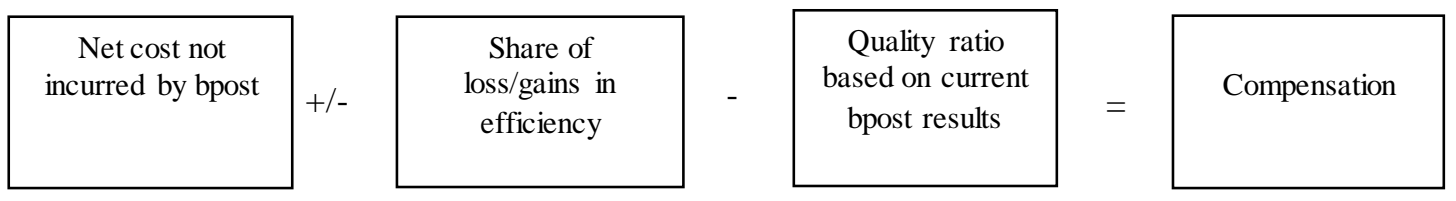

Fig. 2. Compensation mechanism for universal service obligations in Belgium

Source: Own elaboration based on Management Contract (2013)

The compensation mechanism shown in Figure 2 contains an incentive for bpost to increase the efficiency and quality of the universal service provided by including in the loss or gain factors of efficiency and effectiveness, which are based on bpost's current performance. The value corresponding to the profit or loss due to efficiency must be calculated on the basis of the effective reduction of all costs (or increase in total costs) over the entire duration of universal service obligations provided by bpost, compared to the reference year. Gains and losses from efficiency changes are divided between state (33\%) and bpost (67\%). Universal services financing in Belgium is provided in Figure 3 below.

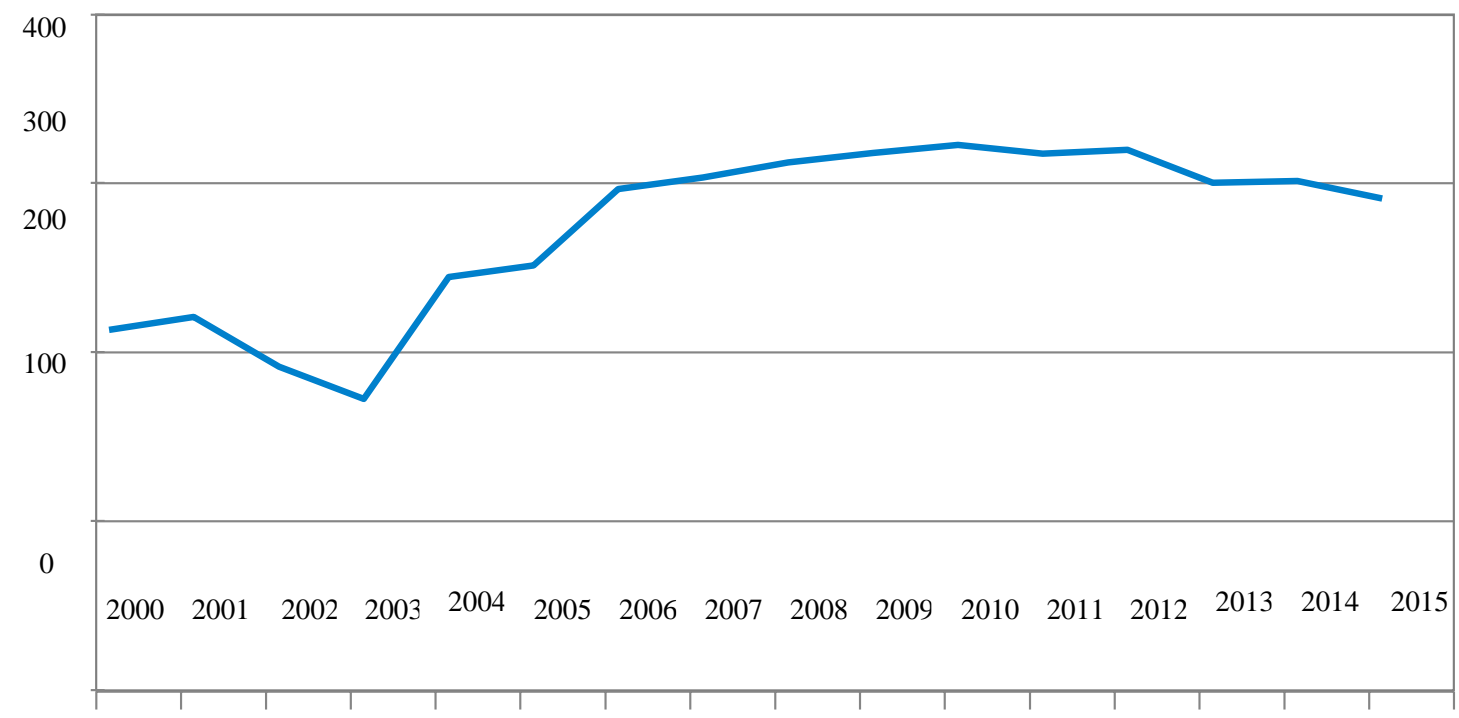

Fig. 3. Universal services financing in Belgium [mln $€]$

Source: Own elaboration based on Decision 2012/321 (2012); Management Contract (2013)

The net cost calculation presented is verified ex-post by the Board, which consists of four persons (commissioners): two bpost shareholders and two from the Court of Auditors. Given that the scope of the universal service provided is greater than in other European Union countries, the amount of financial compensation is also much greater than in other countries. In 2009, the European Commission launched an investigation into the state funds paid out to bpost in 1992-2010. It was revealed that annual compensation of up to $€ 5.2$ billion between 1992 and 2010 was granted to bpost for the supply of newspapers and magazines, partly exceeding the net cost of services estimated on the basis of general economic interest. The European Commission 
ENTREPRENEURSHIP AND SUSTAINABILITY ISSUES

ISSN 2345-0282 (online) http://jssidoi.org/jesi/

2021 Volume 8 Number 3 (March)

http://doi.org/10.9770/jesi.2021.8.3(34)

ordered the reimbursement of $€ 417$ million in 2012 for unjustified support. This decision was challenged by bpost and Post Invest Europe. In 2013, the court found both motions to be unfounded.

In March 2013, Belgium informed the Commission of a planned annual grant of $€ 300$ million to finance the services of general interest entrusted to bpost under the 5th Management Contract for the period 2013-2015. The European Commission has positively assessed the method used to estimate the net cost of universal services. It has determined that the compensation did not exceed the costs of the services and can therefore be transferred within the framework of the permitted public aid.

After the bpost subsidies increased significantly after 2003, they started to decrease slightly from 2012 as a result of the operator's productivity increase. Their value fluctuates around $12 \%$ of annual bpost turnover. In practice, the operator receives more compensation for the provision of the public service mission entrusted to it than for the provision of the standard universal service.

The possibility of introducing a compensation fund to finance the net cost of universal services was eliminated by the postal law. The BIPT identified the advantages and disadvantages of public subsidies and the universal service fund. The Belgian Government chose public funding because of the uncertainty in other funding mechanisms, as is the case with compensation funds (for example, more complex procedures). In addition, their neutral impact on competition is important. However, through high compensation payments (12\% of turnover), bpost is currently the most profitable postal operator in Europe. This raises doubts whether budget subsidies are needed at all.

\section{Compensation Fund in Poland}

In the case of the Polish postal market, the obligation to provide services of general economic interest in 20132015 was imposed on Polish Post (Poczta Polska) in the form of statutory provisions, (Act of 2012, art. 178, sec. 1) to provide universal postal services. Since 2016, the Polish Post (Poczta Polska) has also won the competition for the designated operator for the next 10 years. No universal service which has quality parameters above the standard regulated at European level occur, contrary to Belgium's case. In Poland, financing of the net cost of the designated operator is possible only if the provision of universal services is carried out at an accounting loss. It must be concluded that such an assessment of the unjustified financial burden is in line with the principles underlying the 3rd Postal Directive as it is objective, transparent and accurate, for its appropriate allocation of revenues and costs necessary for the calculation of the loss is guaranteed by the regulatory accounting obligation imposed on the designated operator (Commission Communication, 2016).

In order to possibly compensate the net cost incurred by Polish Post (Poczta Polska), the Polish authorities established a compensation fund mechanism, which was notified to the European Commission. It allows for compensating the costs of Polish Post (Poczta Polska) through contributions from postal service providers (including Polish Post) operating on the universal postal service market and those services which are interchangeable. If necessary, these contributions may be supplemented by subsidies from state budget.

The designated operator shall estimate the projected net cost of the universal service obligation and the accounting loss it expects to incur in connection with the performance of the universal service obligation in a given financial year. The operator is also obliged to submit, by 31 March of the reference year, a corrective action plan to avoid the occurrence of the forecasted loss (if any) in the provision of universal service (at least to minimize it). The recovery plan includes various initiatives to increase business efficiency.

The Postal Law Act art. 3 point 30 contains the definition of "services within the scope of universal services" called "exchangeable services". 
ENTREPRENEURSHIP AND SUSTAINABILITY ISSUES

ISSN 2345-0282 (online) http://jssidoi.org/jesi/

2021 Volume 8 Number 3 (March)

http://doi.org/10.9770/jesi.2021.8.3(34)

The Office of Electronic Communications (Urząd Komunikacji Elektronicznej [UKE]), as the market regulator, verifies the probability of a loss resulting from the provision of universal services, understood as a negative result on the sale of these services, which, under Polish law, confirms an unjustified financial burden for the designated operator. If, in a given financial year, the operator has incurred accounting losses as a result of the universal service obligation, it shall submit to the President of UKE, within seven months, a net cost calculation and the incurred accounting loss together with supporting documents and request for compensation. The President of UKE appoints an independent auditor to verify the documents submitted and within 4 months issues a decision specifying the verified amount of net cost and accounting loss and determining the amount of compensation.

The President of UKE determines the amount of contribution to the fund of postal operators. According to art. 108, sec. 2 of the Postal Law Act, postal operators providing universal services or interchangeable services are obliged to contribute to the compensation fund if their revenue from these services in the reference year exceeded the amount of $€ 0.23$ million. The amount of contribution due from each postal services operator is a product of a uniform percentage index (whose level does not exceed 2\%) and the amount of relevant revenue of each operator obtained in a given year. The market regulator (UKE) considers that the $2 \%$ ceiling is not a significant barrier to the development of postal operators. If the amount of the contributions is not sufficient to cover the entire amount of compensation, the State shall cover the missing part from its own budget.

If there is an accounting loss in the provision of universal service and the net cost of the universal service obligation (calculated in accordance with the net avoidable cost method) is lower than the accounting loss incurred, a value up to the net cost shall be compensated. Conversely, if the net cost is higher than the loss, the designated operator shall be compensated only for the loss (underfunding). Table 5 shows the calculation of the compensation for 2013.

Table 5. Result on universal service obligation in $2013-2015$ [€ mln].

\begin{tabular}{|c|c|c|c|}
\hline Content & $\mathbf{2 0 1 3}$ & $\mathbf{2 0 1 4}$ & $\mathbf{2 0 1 5}$ \\
\hline Revenues from universal services & 756.3 & 683.0 & 619.5 \\
\hline Universal services cost & 778.4 & 675.0 & 561.9 \\
\hline Results from universal service & -22.1 & +8.0 & +57.6 \\
\hline Net cost of universal services & 32.5 & 33.00 & 33.0 \\
\hline Including market benefits & 42.4 & 42.4 & 42.4 \\
\hline Result on sales & 6.3 & 20.0 & 8.3 \\
\hline
\end{tabular}

Source: Own elaboration based on the Polish Post (Poczta Polska) (2017); Commission Communication (2017)

Data included in Table 5 indicate that the net cost components in 2013 for Poczta Polska constitute a burden of about $€ 75.1$ million per year. This is partly offset by indirect benefits from being a designated operator, which amount to around $€ 42.6$ million per year. This leads to the conclusion that if Polish Post (Poczta Polska) did not fulfil the obligation to provide universal postal services, its operating result was $€ 32.6$ million higher per year than the current one, and would amount to over $€ 47.9$ million. The net cost of universal services (including indirect benefits) in Table 5 in the years 2014-2015 has been estimated at a similar level until 2013 as there was a positive result on universal services which releases Poczta Polska from the obligation to calculate the net cost in those periods. The relatively low net cost of universal services in Poland compared to Western European countries is noteworthy. According to the author, one of the reasons may be relatively low labor costs in Poland and quite optimistically estimated indirect benefits due to the role of the designated operator.

In the future, however, the development of the postal market towards e-substitution and e-commerce will reduce the benefits of the universal service obligation in all countries. The decrease in demand for postal services increases the cost of providing the universal service as the decreasing number of items to be delivered increases 
ENTREPRENEURSHIP AND SUSTAINABILITY ISSUES

ISSN 2345-0282 (online) http://jssidoi.org/jesi/

2021 Volume 8 Number 3 (March)

http://doi.org/10.9770/jesi.2021.8.3(34)

delivery cost. This means that the difference between costs and benefits of universal service obligations will increase over time, resulting in significant costs - not only to the operator but also to society (Copenhagen Economics, 2018).

Net settlement for 2013 can be found Table 6 below, which includes potential contributions of operators. In years 2014-2019, no analysis of the settlement of the fund has been made, as Poczta Polska reported positive results on universal services. In 2013, there were 71 alternative postal operators (currently about 80) in the segment of interchangeable services, whose total market share was $4.9 \%$ in terms of revenues. However, only 10 postal operators (including PP) met the revenue threshold and were therefore obliged to contribute to the fund.

Table 6. Settlement of the compensation fund for 2013.

\begin{tabular}{|l|c|l|}
\hline \multicolumn{1}{|c|}{ Analytic positions } & \multicolumn{1}{|c|}{$\begin{array}{c}\text { Amount } \\
{[\mathbf{m l n} \boldsymbol{\epsilon}]}\end{array}$} & \multicolumn{1}{|c|}{ Comment } \\
\hline $\begin{array}{l}\text { Net cost components (including change in } \\
\text { costs and revenues) }\end{array}$ & 75.0 & $\begin{array}{l}\text { Liquidation of unprofitable points, reduction in the frequency of delivery } \\
\text { in rural areas, cost of capital }\end{array}$ \\
\hline Indirect benefits & 42.5 & Estimated total for those listed in Table 1 \\
\hline Net cost of universal services for 2013 & 32.5 & Net cost components minus indirect benefits \\
\hline Level of compensation & 22.1 & Universal service loss size \\
\hline $\begin{array}{l}\text { Polish Post participation in the } \\
\text { compensation fund }\end{array}$ & 19.7 & $\begin{array}{l}2 \% \text { of Polish Post revenue from universal services and replacement } \\
\text { services to total market revenues }\end{array}$ \\
\hline Payment amount for PP & 2.4 & The difference between loss and "own contribution" to the fund \\
\hline Alternative operators & 1.0 & $\begin{array}{l}2 \% \text { of revenues of alternative operators, namely: PLN 219.8 million } \\
\text { [UKE, 2014, p. 27] }\end{array}$ \\
\hline State budget & 1.4 & Missing amount after alternative operator payment \\
\hline
\end{tabular}

Source: Own estimates.

The data contained in Table 6 confirm that even if there is a loss on universal services, a significant part of this loss has to be covered by Polish Post (Poczta Polska) on its own, due to the market share (over 95\%). Only €2.3 million is compensated, while the additional burden on the operator exceeds $€ 74.4$ million. In turn, the financial condition of the Polish Post (Poczta Polska) deteriorates. In 2016, for the first time in 10 years, it recorded a balance sheet loss. At the same time, the Polish Post (Poczta Polska) has not received any aid from the State budget in recent years. The situation varies in other EU countries. Germany invested so much in Deutsche Post that it does not even need to establish a designated operator. Deutsche Post is the world's largest logistics and postal group, which enters foreign markets and provides a higher standard of services than that provided for universal postal services (Instytut Pocztowy [Postal Institute], 2014).

\section{Discussion}

Two basic approaches of universal service net cost financing be identified. These include financing through direct subsidies from the public sector or using a compensation fund usually financed by postal sector entities. Universal services may also be partially financed through public procurement. It should be noted that this is not a method for financing the universal services in the strict sense of the term, but rather a form of contracting and delivering them. In theory, one can also consider the model of monopolization with the possibility of price regulation and product diversification, however they are a form of financing within the postal industry. In practice, these methods are not applied because they would restrict competition.

Public funding from the budget seems to be the preferred solution. The state, when defining the scope of the universal service, shall also bear its costs in this respect. This increases the reliability of the services but it entails the risk that the universal service provider will assume that all losses will be compensated for by state subsidies, 


\section{ENTREPRENEURSHIP AND SUSTAINABILITY ISSUES}

ISSN 2345-0282 (online) http://jssidoi.org/jesi/

2021 Volume 8 Number 3 (March)

http://doi.org/10.9770/jesi.2021.8.3(34)

which will not provide an incentive to reduce costs. However, as indicated by the research, the creation of compensation funds leads to the conclusion that without a significant participation in the proceeds of public funds, it is not possible to effectively finance the costs of the implementation of universal postal services in the amounts constituting an unjustified burden on the designated operator.

Financing of the universal services by the state is particularly justified for countries where the burden of the net cost of postal services is high in comparison with the funds that can be obtained from charges from operators or their customers. Undoubtedly, direct subsidies that reimburse additional costs incurred are effective and do not significantly affect market competition. By financing the universal service by means of budget contributions, the costs of the universal service are shared by society as a whole, not just market participants. In addition, if government subsidies are financed by progressive taxes, the mechanism may be more socially fair. There are obviously risks and temptations of overcompensation, which will have a negative impact on competition in which the operator functions. Where the government plays the dual role of investor and supervisor, budgetary financing must be transparent with regards to the estimation of the net cost and implementation of subsidies. $*$

In Italy, a compensation fund method is used. Payments from postal operators collected through the fund between 2000 and 2010 amounted to $0.01 \%$ of universal postal service net costs (Fratini, 2016). For example, the contribution to the compensation fund of other service providers was only $€ 111,000$ in 2005 (representing $0.04 \%$ of the net cost of universal service). Contributions paid to the compensation fund proved to be insufficient to cover the costs of the universal postal service. As a result of state intervention, budget subsidies of approximately 370 million per year for the provision of the universal postal service were transferred to Poste Italiane. The European Commission verified the compensation for Poste Italiane in the years 2000-2011 (European Commission Decision, 11.2012) and ruled that the payments were in line with the internal market, as the net cost of the provided universal services significantly exceeded the value of the subsidy (e.g. in 2010, the net cost of the universal services was $€ 689$ million and the compensation was $€ 364.5$ million).

A formal verification of the net cost of the universal postal service of the Italian market regulator (AGCom), performed for the first time in 2014 for the years 2011 and 2012 using the net unpaid method, indicated that it amounted to $€ 709$ million and $€ 704$ million respectively. This means that the compensation of $€ 380.6$ million for 2011 and $€ 327.3$ million for 2012 covered only half of the net costs of the universal postal service. For the period 2015-2019, government subsidies for the provision of the universal postal service have been set at $€ 262.4$ million per year regardless of the net cost estimates of the universal service.

In Germany, a universal service compensation fund was not set up as no universal service deficiencies were observed. The universal postal service is financed by revenues generated by Deutsche Post DHL. In addition, Deutsche Post receives substantial subsidies for its pension costs, which have been the subject of an in-depth investigation by the European Commission. Pension subsidies increased from $€ 151$ million in 1995 to $€ 3.2$ billion in 2010, which means that they amounted to around $€ 37$ billion over the period 1995-2010 (Commission Decision 2012/636). Deutsche Post voluntarily deals with the provision of universal services and their financing, mainly by building a positive image. It is estimated that the image loss, defined as indirect benefits, could be greater than the expected savings after the abandonment of universal service. In addition, Deutsche Post would probably lose its VAT exemption.

Postal services market in France were fully opened up to competition in early 2011. La Poste receives two types of public subsidies: compensation for the reduced rate for the press and subsidies for maintaining a dense postal network. La Poste received compensation for the reduced press rate of $€ 242$ million a year in the period 20052011. Later, the French government reduced compensation by 50 million $€$ in 2014 and 2015. The compensation

\footnotetext{
$\$$ In order to meet the legal requirements, the funding must meet the four criteria set out in Altmark (2003).
} 


\section{ENTREPRENEURSHIP AND SUSTAINABILITY ISSUES}

ISSN 2345-0282 (online) http://jssidoi.org/jesi/

2021 Volume 8 Number 3 (March)

http://doi.org/10.9770/jesi.2021.8.3(34)

for maintaining adequate network density is approximately $€ 150$ million. The net cost to La Poste of maintaining a dense postal network is set at $€ 269$ million for 2010 and $€ 277$ million for 2011 . Unlike the compensation payments for lower press costs, the subsidy to provide a dense postal network increases. The European Commission has accepted the subsidy given to La Poste to maintain a dense network of postal services for the period 2008-2012, since it represented only a part of the net cost of the relevant public service tasks (Commission Decision, January 2012).

Great Britain was one of the first countries in Europe to introduce competition on the postal services market in 2006. The Postal Services Act of 2011 provides that the UK Government is taking over part of Royal Mail's (RMPP) commitments. A pension system has been established which is a burden on the UK Government. As of 31 March 2012, Royal Mail is only obliged to pay pension contributions to employees who still work for Royal Mail. As a result, it is only responsible for new pension rights acquired after March 2012 (Commission Decision 03.2015).

Royal Mail and Post Office Ltd. (POL), which also deals with retail sales, receives financial support for maintaining the rural network, subsidies for transforming the network of post offices and exemption from pension costs. POL has received annual compensation for the maintenance of the network in rural areas which amounted to up to $£ 150$ million by 2010 . The compensation increased to $£ 280$ million between 2015 and 2016. The Government has granted Royal Mail a debt reduction of $£ 1.089$ billion over the period 2010-2015, and £184 million for the costs of closing down post offices on the basis of restructuring plans. The European Commission has reviewed both programmes, declaring them legal (Commission Decision 03.2012; Commission Decision 11.2007). The European Commission has also adopted a $£ 32.2$ billion scheme to relieve Royal Mail of pension costs.

The postal market in Spain was liberalized in 2011. Correos is obliged to provide universal postal services by the end of 2026 (Postal Law, 2010). In 2011, a compensation fund for universal services was established. Although has not been implemented yet, the methodology has already been defined. The fund shall be paid for from various sources. Government subsidies, postal operators' fees, license fees and interest on the collected funds will be the basic source of funds. Correos will be the only exempt operator. Once the net cost and unjustified burden for a given year have been determined, the designated operator shall receive their value. In the event that the components of the fund are not sufficient to compensate for the costs of providing universal service, the difference will be paid by the central budget. In addition, since 2008, Correos has been receiving capital subsidies (€ 5-20 million per year) and subsidies for employee training. The total amount transferred decreased from $€ 627$ million in 2008 to $€ 171$ million in 2014 (Annual Reports, 2008-2014).

Correos receives compensation payments for the provision of universal services in advance on the basis of net cost calculations from previous years. After the end of a given year, the actual net cost of providing the universal service shall be estimated and a final settlement shall take place. For example, in 2013 Correos received outstanding payments for 2009 ( $€ 148$ million) and 2010 ( $€ 121$ million). For the 3-year period 2011-2013, a payment of $€ 518$ million was transferred in 2014. The value of compensations paid out has been increasing in recent years, from $€ 40$ million in 2011-2012 to $€ 337$ million in 2014.

When considering the methods of universal postal service financing, direct subsidy is proving to be the most effective source of financing on European markets. The advantage of this alternative is the clear responsibility of the central budget for ensuring an adequate level of universal service and its financing. A direct subsidy provides full financing of the universal service based on the estimated cost of the obligation, but is often difficult to determine reliably. These difficulties can be eliminated by linking subsidies to additional activities of postal operators, as is the case on European markets. In the UK, the Government provides a subsidy to enable Royal Mail to maintain post offices in rural areas. By limiting the subsidy to dedicated activities, it facilitates the linking 


\section{ENTREPRENEURSHIP AND SUSTAINABILITY ISSUES}

ISSN 2345-0282 (online) http://jssidoi.org/jesi/

2021 Volume 8 Number 3 (March)

http://doi.org/10.9770/jesi.2021.8.3(34)

of the subsidy to specific costs. The French government is compensating the national operator La Poste for the reduction in payments for press. In Belgium, the subsidies mainly concern non-standard public service mission. All these solutions lead to strong support of national postal operators. In this context, the situation of Polish Post (Poczta Polska) is different because in practice, through the application of the compensation fund, it does not receive any financial support for the provision of universal services. This deteriorates its financial situation and competitiveness, especially on international markets in the area of e-commerce.

The ineffectiveness of financing through the compensation fund is also confirmed by the fact that, the Polish Post (Poczta Polska) has not yet received any amounts to cover the net cost due to the settlement of the compensation fund for 2013, despite the positive opinion of the European Commission on the justification of granting such aid. Adoption of a compensation fund model through subsidies of postal operators as the preferred solution for financing the net cost leads to a situation in which the designated operator is obliged, almost independently, to finance the burden resulting from the net cost. Consequently, the designated operator is destined to operate in a much less friendly regulatory environment than other entities, which should be considered a significant shortcoming of the postal market liberalization process in Poland. Moreover, as indicated by other studies (Borowiec, 2018), postal operators which function simultaneously on regulated universal services and fully competitive markets, by using a single cost calculation model (e.g. ABC) may have distorted information about the result on universal services. The author proves the existence of the so-called universal services result paradox, which causes an improvement in operating result with decreasing volumes of services and constant regulatory requirements. On the basis of this evidence, further consideration was given to the need to modify the $\mathrm{ABC}$ model together with a proposal for a methodological basis determined using the net cost of universal service. The consequence of which is an overstatement of the result on universal services, which results in limiting the potential amount of co-financing, either from a direct subsidy or a compensation fund.

\section{Conclusions}

In the case of the postal market, the regulations at EU level provide for the possibility to finance the activities of the operator within the framework of the imposed obligation, but without any absolute obligation on the part of public authorities to finance those services. For the universal service net cost financing, a distinction can be made between financing through direct subsidies or compensation funds usually financed by postal operators.

In almost all Western European countries (e.g. Belgium, France, Italy, Spain and the UK), the designated operator receives direct or indirect payments from the public sector. Subsidies can directly finance the cost of the universal service (Spain, Italy), maintain the postal network (UK, France and Belgium) or support selected processes, for example press delivery (France and Belgium). A positive aspect of financing the postal service by the public sector is responsibility or greater availability of funds. This method ensures secure funding, which increases the reliability of compensation paid to the operator (this was the reason why the fund was abandoned in Belgium). It is also characterized by relatively low administrative costs. However, it does not provide an incentive to reduce the costs of universal service, as it is financed by the government. Excessive compensation may have a negative impact on competition as it may be open to abuse by the service provider. Through public funding, the cost of service provision is shared by society on a larger scale. The risk of public financing lies in a potential allegation by the European Commission of unjustified financing of the postal operator, although in the case of the compensation fund there is also a necessity to notify the EC of the potential financial aid.

The compensation fund shall be financed by contributions imposed on postal service providers or their users. Almost all countries (Poland, France, Germany, Italy, Spain and the United Kingdom) have the legal basis to establish a compensation fund. Contributions to the fund are usually limited, as they represent several percent of the universal service provision net cost (e.g. in Poland, Italy). As the study demonstrates, there are difficulties in collecting contributions from operators. In practice, the compensation fund is not sufficient and must be 
ENTREPRENEURSHIP AND SUSTAINABILITY ISSUES

ISSN 2345-0282 (online) http://jssidoi.org/jesi/

2021 Volume 8 Number 3 (March)

http://doi.org/10.9770/jesi.2021.8.3(34)

supported by public funds. The disadvantage of the compensation fund is that the net cost has to be compensated by market participants, which may lead to a situation where the beneficiary will have to finance itself to a large extent. Moreover, it sets high requirements for all postal operators due to the requirement to keep separate accounting and the obligation to submit annual reports. The compensation fund is administratively expensive (examination of financial data of all operators, calculation of base contribution, fund management). The pros compensation funds lie in the fact that universal services are financed by the industry, without burdening public finances. The results of the research carried out in this study and European experience suggest that compensation funds are not an appropriate mechanism for financing the net costs of postal services.

The study has shown that the preferred form net cost financing should be fully paid from state budget. Additionally, it should be considered unjustified to charge the full value of the net cost to the operator as the actual burden and not only the amount of the loss on universal service. It should be stressed that the mechanism for subsidizing services of general economic interest (SGEIs) implemented directly from budget resources is already in place (in the rail, postal and telecommunications sectors). A similar financing mechanism should apply to services of general economic interest (SGEIs) in the entire postal market, namely, for universal service net cost financing.

\section{References}

5th Management Contract, 2013. Art. 5-6, 12, 22. https://www.bpost.be/en/pdf/RD_May_29_2013_5th_Management_Agreement.pdf

Accenture, (2015). Achieving High Performance in the Post and Parcel Industry, Accenture Research and Insights, p. 7. https://www.accenture.com/us-en/insight-achieving-high-performance-post-and-parcel-industry

Altmark, 2003. Sprawa c-280/0 Altmark Trans GmbH i Regierungspräsidium Magdeburg v Nahverkehrsgesellschaft Altmark GmbH. https://www.studocu.com/fr-ca/document/libera-universita-internazionale-degli-studi-sociali-guido-carli/diritto-europeo/notesde-cours/altmark-diritto-europe o/4547336/view

Anderson, S.P., De Palma, A., \& Kreider, B. (2001). The efficiency of indirect taxes under imperfect competition. Journal of Public Economics, 81(2), 231-251. https://doi.org/10.1016/S0047-2727(00)00085-2

Anton, J., VanderWeide, J. H., \& Vettas, N. (2002). Entry Auctions and Strategic Behaviour under Cross-Market Price Constraints. International Journal of Industrial Organization, 20, 611-629. https://doi.org/10.1016/S0167-7187(01)00055-8

Armstrong, M., Doyle, C., \& Vickers, J. (1996). The access pricing problem: A synthesis. Journal of Industrial Economics, 44(2), 131-150. https://doi.org/10.2307/2950642 http://www.ingenta.com/journals/browse/bpl/joie

Bergum, K. (2008). Calculating the net cost of the USO: A practical example from Norway, Handbook of Worldwide Postal Reform, 110119. https://www.elgaronline.com/view/9781847209573.xml, https://doi.org/10.4337/9781848444904.00013

Blagojevic, M., Ralevic, P., \& Sarac, D. (2020). An integrated approach to analysing the cost efficiency of postal networks. Utilities Policy, Vol. 62, Number 101002. https://doi.org/10.1016/j.jup.2019.101002

Bloch, F., \& Gautier, A. (2008). Access pricing and entry in the postal sector. The Review of Network Economics, 7(2), 207-230. http://www2.ulg.ac.be/crepp/papers/crepp-wp200606.pdf

Boldron, F., Borsenberger, C., Joram, D., Lécou, S., \& Roy, B. (2009). A dynamic and endogenous approach to financing the USO in a liberalized environment, in Crew, M.A.; Kleindorfer P. R. (Ed.) Progress in the Competitive Agenda in the Postal and Delivery Sector, Edward Elgar, Cheltenham, UK, Northampton, MA 67-82. http://www.e-elgar.com/bookentry_main.lasso?id=13248 https://doi.org/10.4337 / 9781848447288.00011

Borowiec, L. (2011). Metoda weryfikacji kosztu netto usług powszechnych jako nieuzasadnionego obciążenia operatora wyznaczone go [Method of verifying the universal service net cost as an unjustified burden on the designated operator], in Nowak E.; Nieplowicz 
ENTREPRENEURSHIP AND SUSTAINABILITY ISSUES

ISSN 2345-0282 (online) http://jssidoi.org/jesi/

2021 Volume 8 Number 3 (March)

http://doi.org/10.9770/jesi.2021.8.3(34)

M. (Ed.) Prace Naukowe Uniwersytetu Ekonomicznego we Wrocławiu nr 181 Rachunkowość a controlling, Wrocław, 44-54. http://yadda.icm.edu.p1/yadda/element/bwmeta1.element.ekon-element-000171375129

Borowiec, L. (2012). Koncepcja kosztu netto usług komunalnych w Polsce [The concept of net cost of utilities in Poland], in Nowak, E.; Nieplowicz, M. (Ed.) Prace Naukowe Uniwersytetu Ekonomicznego we Wrocławiu nr 252, Instrumenty zarzadzania kosztami $i$ dokonaniami, Wrocław, 42-53. $\quad$ http://yadda.icm.edu.pl/yadda//element/bwmeta1.element.ekon-element000171229441?printV iew=true

Borowiec, L. (2013). Szacowanie kosztu netto usługi powszechnej na wybranym przykładzie [Estimating the net cost of universal service on the chosen example], in Nowak E.; Nieplowicz, M. (Ed.) Prace Naukowe Uniwersytetu Ekonomicznego we Wrocławiu nr 289, Systemy rachunku kosztów $i$ kontroli zarządczej, Wrocław, 91-101. http://yadda.icm.edu.pl/yadda/e lement/bwmeta1.element.ekon-element-000171258159

Borowiec, L. (2018). Rachunek kosztów działań a potrzeby informacyjne podmiotów świadczących powszechne usługi pocztowe [Activity costing and information needs of universal postal service providers]. Aspekty regulacyjne i zarządcze, Wydawnictwo AEH, Warszawa.

Borsenberger, C., Cremer, H., De Donder, P., Joram, D., \& Roy, B. (2010). Funding the cost of universal service in a liberalized postal sector, Heightening Competition in the Postal and Delivery Sector, 220-234. 10.1007/978-1-4615-4481-4_3, http://www.elgar.com/bookentry_main.lasso? $\mathrm{id}=13672$

Bourguignon, H., \& Ferrando, J. A. (2007). Skimming the Others. Cream: Competitive Efects of an Asymmetric Universal Service Obligation. International Journal of Industrial Organization, 25, 761-790.

Cahill, C., Palcic, D., \& Reeves, E. (2018). Striving to deliver: commercialization and performance in Ireland's postal sector. Annals of Public and Cooperative Economics, 89(3), 527-541. https://doi.org/10.1111/apce.12178

Calzada, J. (2009). Universal service obligations in the postal sector: The relationship between quality and coverage, Original research article. Information Economics and Policy, 21(1), 10-20. https://doi.org/10.1016/j.infoecopol.2008.07.002

Choné, P., Flochel, L., \& Perrot, A. (2002). Allocating and Funding Universal Service Obligations in a Competitive Market. International Journal of Industrial Organization, 20, 1247-1276. https://doi.org/10.1016/S0167-7187(01)00077-7

Cohen, R., McBride, C., \& Panzar, J.C. (2010). The cost of the USO in the United States, Heightening Competition In The Postal And Delivery Sector, Book Series: Advances in Regulatory Economics, 253-262, http://www.eelgar.com/bookentry_main. lasso? id=13672

Copenhagen Economics, (2008). What is the cost of Post Denmark's Universal service obligation? Copenhagen.

Copenhagen Economics, (2018). Report on USO net costs in https://www.copenhageneconomics.com/publications/publication/report-on-uso-net-costs-in-iceland

Cremer, H., Grimaud, A., Laffont, J.J. (2000). The Cost of Universal Service in the Postal Sector in Crew, M.; Kleindorfer, P. (Ed.). Current Directions in Postal Reform, Kluwer Academic Press, Boston (MA).

De Donder, P. (2006). Access pricing in the postal sector: Theory and simulations. Review of Industrial Organisation, 28(3), 307-326. https://doi.org/10.1007/s11151-006-0017-5

De Villemeur, E.B., Cremer, H., Roy, B., \& Toledano, J. (2003). Optimal Pricing and Price-Cap Regulation in the Postal Sector. Journal of Regulatory Economics, 24 (1), 49-62. https://doi.org/10.1023/A:1023948014513

Decision 2012/321 of the Commission $\quad$ of $\quad 25 \quad$ January 2012 . https://ec.europa.eu/competition/state_aid/cases/232315/232315_1314149_177_2.pdf

Decyzja Komisji 2012/636 z 25 stycznia 2012. Complaint against Germany for unlawful state aid to Deutsche Post, OJ L289. https://ec.europa.eu/competition/state_aid/cases/221961/221961_1314187_452_2.pdf

Decyzja Komisji z 19 marca 2015. Sprawa SA 38788. [Commission decision of 19 March 2015. Case SA 38788.] 


\section{ENTREPRENEURSHIP AND SUSTAINABILITY ISSUES}

ISSN 2345-0282 (online) http://jssidoi.org/jesi/

2021 Volume 8 Number 3 (March)

http://doi.org/10.9770/jesi.2021.8.3(34)

Decyzja Komisji z 21 marca 2012. Sprawa SA 31479 [Commission decision of 21 March 2012. Case SA 31479], UK - Royal Mail, OJ L279. file:///C:/Users/cciadmin/Downloads/2012_1_279_1_27920121012p100400068.pdf

Decyzja Komisji z 28 listopada 2007. Pomoc państwa N 388/2007 - Zjednoczone Królestwo [Commission decision of 28 November 2007. State aid N 388/2007 - United Kingdom,], Post Office Limited (POL) transformation programme (Dz. U. C 14 z 19.1.2008, s. 19).

Decyzja Komisji z dnia 25 stycznia 2012. Sprawa SA 34027 [Commission decision of 25 January 2012. Case SA 34 027] (Abattement fiscale en faveur de La Poste pour le financement de la presence territorial).

Decyzje Komisji Europejskiej C(2006) 4206 ostateczna 26.9.2006, C(2008) 1606 ostateczna z dnia. 30.4.2008, oraz C(2012) 8230 wersja ostateczna z dnia 20.11.2012 [Decisions of the European Commission C(2006) 4206 final 26.9.2006, C(2008) 1606 final of the European Parliament and of the Council of 26.9.2006. 30.4.2008, and C(2012) 8230 final of 20.11.2012].

Dieke, A., \& Junk, P. (2015a). Alternative Funding Models for the Universal Service Obligation: The European Experience. WIK Report, Bad Honnef.

Dieke, A., \& Junk, P. (2015b). Funding the Universal Service Obligation, RARC Report RARC-WP-16-005. WIK Report, Bad Honnef 2015. https://www.uspsoig.gov/sites/default/files/document-library-files/2016/RARC-WP-16-005.pdf

Dietl, H., Jaag, C., Lang, M., Lutzenberger, M., \& Trinkner, U. (2011). Impact of VAT exemptions in the postal sector on competition and welfare. In Crew, M. \& Kleindorfer, P. (Ed.) Reinventing the Postal Sector in an Electronic Age. Edward Elgar, Cheltenham, 267- 280. https://doi.org/10.4337/9781849805964.00024

Dietl, H.M., Grütter, A., \& Lutzenberger, M. (2001). Methods of Estimating the Cost of the Universal Service Obligation, First Conference of the Global Postal Research and Educational Network, University of Zurich, Dimensions of services switching costs and managing their differential strategic outcomes. Journal of Business Research:441-450.

Dobrodolac, M., Blagojevic, M., Draskovic, D., \& Svadlenka, L. (2018). Development trends in the structure of services of the public postal operator in Serbia. International Conference on traffic and transport engineering (ICTTE), (Ed.) Cokorilo, O., 534-539.

Dobrodolac, M., Ralević, P., Švadlenka, L., \& Radojičić, V. (2016). Impact of a new concept of universal service obligations on revenue increase in the post of Serbia. Promet - Traffic \&Transportation, 28(3), 235-244. https://hrcak.srce.hr/165522

Dyrektywa Parlamentu Europejskiego i Rady 2008/6/WE z dnia 20 lutego 2008 r. zmieniająca dyrektywę 97/67/WE w odniesieniu do pełnego urzeczywistnienia rynku wewnętrznego usług pocztowych Wspólnoty [Directive 2008/6/EC of the European Parliament and of the Council of 20 February 2008 amending Directive 97/67/EC with regard to the full accomplishment of the internal market of Community postal services]. http://data.europa.eu/eli/dir/2008/6/oj

ERGP, (2012). Net Cost Calculation and Evaluation of a Reference Scenario. file:///C:/Users/cciadmin/Downloads/ergp-11-17-rev1_en\%20(1).pdf

Foros, O., Kind, H. J. (2003). The Broadband Access Market: Competition, Uniform Pricing and Geographical Coverage. Journal of Regulatory Economics, 23, 215-235. https://ideas.repec.org/a/kap/regeco/v23y2003i3p215-35.html

Fratini, A. (2016). Compensation Fund Under EU Law: A Suitable Solution for the Postal Market?, in Crew, M.; Brennan, T.J. (Ed.). The Future of the Postal Sector in a Digital World, Springer International Publishing, New York. https://www.springer.com/gp/book/9783319244525\#aboutAuthors

Frontier Economics, (2008). Net costs of elements of the Universal service, London.

Frontier Economics, (2012). Report: Study on the principles used to calculate the net costs of the postal USO: 126-127 i 129. (http://ec.europa.eu/internal_market/post/doc/studies/2012-net-costs-uso-postal_en.pdf).

Gautier, A., \& Mizuno, K. (2011). Gradual Network Expansion and Universal Service Obligations. Annals of Public and Cooperative Economics, 82, 97-113. https://online library.wiley.com/doi/abs/10.1111/j.1467-8292.2011.00432.x

Gautier, A., \& Paolini, D. (2011). Universal Service Financing in Competitive Postal Markets: One Size Does Not Fit All. Review of Network Economics, 10, 1-28. https://doi.org/10.2202/1446-9022.1227 
ENTREPRENEURSHIP AND SUSTAINABILITY ISSUES

ISSN 2345-0282 (online) http://jssidoi.org/jesi/

2021 Volume 8 Number 3 (March)

http://doi.org/10.9770/jesi.2021.8.3(34)

Gautier, A., \& Wauthy, X. (2010). Price Competition under Universal Service Obligations. International Journal of Economic Theory, 6, 311-326. https://doi. org/10.1111/j.1742-7363.2010.00137.x

Hoernig, S.H. (2006). Should uniform pricing constraints be imposed on entrants? Journal of Regulatory Economics, 30(2), 199-216. https://doi.org/10.1007/s11149-006-0013-6

Hostakova, D. (2018). Identification of the requirements of customers of the postal company on the spatial availability of access and contact points of the public postal network, CBU International Conference proceedings 2018: Innovations in Science and Education, (Ed.) Hajek P.; Vit O., Proceedings of CBU, 6, 187-192. https://doi.org/10.12955/cbup.v6.1154

Instytut Pocztowy, (2014). Instytucja pocztowego operatora wyznaczonego w Unii Europejskiej. Przegląd rozwiązań krajowych w zakresie świadczenia pocztowych usług publicznych w 27 państwach Unii Europejskiej [Institution of the postal operator designated in the European Union. Review of national solutions for provision of public postal services in the 27 countries of the European Union], Warsaw, p: 8.

Jaag, C. (2011a). Entry Deterrence and the Calculation of the Net Cost of Universal Service Obligations. Review of Network Economics, 10(1), Article 4. https://doi.org/10.2202/1446-9022.1189

Jaag, C. (2011b). What is an Unfair Burden? Compensating the Net Cost of Universal Service Provision. Review of Network Economics, 10(3), Article 7. https://doi.org/10.2202/1446-9022.1225

Jaag, C., \& Trinkner, U. (2011). The interaction between universal service costing and financing in the postal sector: A calibrated approach. Journal of Regulatory Economics, 39(1), 89-110. https://doi.org/10.1007/s11149-010-9138-8

Jaag, C., Koller, M., \& Trinkner, U. (2009). Calculating the cost of the universal service obligation: the need for a global approach, Progress in the Competitive Agenda in the Postal and Delivery Sector, Publisher: Edward Elgar, Cheltenham. https://doi.org/10.5167/uzh-20559

Komunikat Komisji do Parlamentu Europejskiego, Rady Europejskiego Komitetu Ekonomiczno-Społecznego i Komitetu Regionów, Ramy jakości dotyczące usług świadczonych w interesie ogólnym [Commission communication to the European Parliament, the Council of the European Economic and Social Committee and the Committee of the Regions, Quality framework for services of general interest], Brussels, 20.12.2011, $\operatorname{COM}(2011)$ 900. https://ec.europa.eu/transparency/regdoc/rep/1/2011/PL/1-2011-900$\underline{\text { PL-F1-1.Pdf }}$

Komunikat Komisji Europejskiej [European Comission Communication], 2015. State aid: Commission approves financing of Polish Post's universal service obligation via a compensation fund, Brussels, http://europa.eu/rapid/press-re lease_IP-15-6176_en.htm

KPMG, (2009). Analyse de la méthode de calcul des coûts du service universel, Paris. https://www.ibpt.be/public/files/fr/1427/3049_fr_management_rapportversionfinale-fr.pdf

KPMG, (2010). Poczta Polska. Koszt netto usług powszechnych. Wybór metodologii [Net cost of universal services. Choice of methodology], Warszawa.

Lewandowski, M., Mlodkowski, P., \& Wrobel, M. (2019). Digital Platforms for Postal Services in EU and Japan. European Integration Studies, 13, 117-130. 10.5755/j01.eis.0.13.22897

Mercier, A., Souche-Le Corvec, S., \& Ovtracht, N. (2020). Measure of accessibility to postal services in France: A potential spatial accessibility approach applied in an urban region. Papers in Regional Science. https://doi.org/10.1111/pirs.12564

Milutinovic, J., Markovic, D., Stanivukovic, B., Svadlenka, L., \& Dobrodolac, M. (2020). A Model For Public Postal Network Reorganization Based On Dea And Fuzzy Approach. Transport, 35(4), 401-418. https://doi.org/10.3846/transport.2020.13741

Mirabel, F., Poudou, J.-C., Roland, M. (2009). Universal service obligations: The role of subsidization schemes. Information Economics and Policy, 21(1), 1-9. https://doi. org/10.1016/j.infoecopol.2008.07.003

Mostarac, K., Kavran, Z., \& Rakic, E. (2019). Accessibility of Universal Postal Service According to Access Points Density Criteria: Case Study of Bjelovar-Bilogora County, Croatia. Promet-Traffic \& $\quad$ Transportation, $31(2), \quad 173-183$. https://doi.org/10.7307/ptt.v31i2.3019

NERA. (1998). Costing and Financing of Universal Services in the Postal Sector in the European Union, A report to DGXIII, London. 
ENTREPRENEURSHIP AND SUSTAINABILITY ISSUES

ISSN 2345-0282 (online) http://jssidoi.org/jesi/

2021 Volume 8 Number 3 (March)

http://doi.org/10.9770/jesi.2021.8.3(34)

OFTEL. (1995). Universal Telecommunications Services: Consultative Document on Universal Services in the UK from 1997.

Oxera. (2007). Funding universal service obligations in the postal sector. Report prepared for La Poste, De Post-La Poste, Hellenic Post, Poste Italiane, P\&T Luxembourg, Correos, Magyar Posta, Cyprus Post, Poczta Polska. https://www.oxera.com/wpcontent/uploads/2018/03/Funding-the-USO-in-the-postal-sector.pdf

Panzar, J. (2000). A Methodology for Measuring the Costs of Universal Service Obligations. Information Economics and Policy, 12(3), 211-220. http://www.sciencedirect.com/science/artic le/pii/S0167-6245(00)00013-5

Panzar, J.C. (2008). Funding Universal Service Obligations. Handbook of Worldwide Postal Reform, 98-109. https://www.elgaronline.com/view/9781847209573.xml https://doi.org/10.4337 /9781848444904.00012

Poczta Polska, (2017). Sprawozdanie z prowadzonej rachunkowości regulacyjnej za rok obrotowy zakończony 31 grudnia 2015 roku [Report on the regulatory accounting for the financial year concluded on 31 December 2015], https://www.uke.gov.pl/s prawozdanie-poczty-polskiej-z-rachunkowosci-regulacyjnej-za-rok-2015-20422

Postcomm. (2001). An assessment of the costs and benefits of Consignia's current Universal Service Provision, London.

Poudou, J.C., \& Roland M. (2014). Efficiency of uniform pricing in universal service obligations. International Journal of Industrial Organization, 37, 141-152, https://doi.org/10.1016/j.ijindorg.2014.08.006

Prawo pocztowe z 30 grudnia 2010 [Postal law of 30 December 2010]. (Ley 43/2010), Hiszpania. https://www.boe.es/eli/es/1/2010/12/30/43

PricewaterhouseCoopers (PwC), (1988). The Impact of Liberalization of Cross-Border Mail.

Ralević, P., Dobrodolac, M., Švadlenka, L., Šarac, D., \& Đurić, D. (2020). Efficiency and productivity analysis of universal service obligation: a case of 29 designated operators in the European countries. Technological and Economic Development of Economy, 26 (4), 785-807. https://doi. org/10.3846/tede.2020.12062

Raporty roczne [Annual reports] 2008-2014. Correos, https://www.correos.es/COREstaticos/

Rodriguez, F., \& Storer, D. (2000). Alternative Approaches to Estimating the Cost of the USO in Posts, Information Economics and Policy, 12(3), 285-299. https://doi.org/10.1016/S0167-6245(00)00010-X

Rozbiecki, M., Rosiak, W. (2014). Koszt netto pocztowej usługi powszechnej i jego finansowanie [Net cost of universal postal services and its financing], Internetowy Kwartalnik Antymonopolowy i Regulacyjny, 2(3). https://ikar.wz.uw.edu.pl/numery/16/pdf/23.pdf

Sarac, D., Kopic, M., Mostarac, K., Kujacic, M., \& Jovanovic, B. (2016). Application of set covering location problem for organizing the public postal network. Promet-Traffic \& Transportation, 28(4), 403-413. doi: 10.7307/ptt.v28i4.1962

Sarac, D., Unterberger, M., Jovanovic, B., Kujacic, M., Trubint, N., \& Ozegovic, S. (2017). Postal network access and service quality: Expectation and experience in Serbia. Utilities Policy, 48, 69-75, https://doi. org/10.1016/j.jup.2017.09.004

Traktat o Unii Europejskiej i Traktatu o funkcjonowaniu Unii Europejskiej opublikowanego w Dz. Urz. UE 2016 C 202. [Treaty on European Union and the Treaty on the Functioning of the European Union published in OJ EU 2016 C 202]

Urząd Komunikacji Elektronicznej, 2018. Raportu o stanie rynku pocztowego za rok 2017 [Office of Electronic Communications, 2018. Report on the state of the postal market for 2017], Warsaw. https://eur-lex.europa.eu/legalcontent/PL/TXT/?uri=OJ\%3AC\%3A2016\%3A202\%3ATOC

Ustawa z 21 marca 1991. Art. 142. par. 1-2 Art. 141 oraz 144 [Act of 21 March 1991. Art. 142 sec. 1-2, art. 141 and 144] (Loi portant rÈforme de certaines entreprises publiques Èconomique).

Ustawa z dnia 23 listopada 2012 r. Prawo pocztowe, [Act of 23 November 2012, Postal law], (Dz. U. z 29.12.2012, poz. 1529). http://prawo.sejm.gov.pl/isap.nsf/download.xsp/WDU20120001529/T/D20121529L.pdf 
ENTREPRENEURSHIP AND SUSTAINABILITY ISSUES

ISSN 2345-0282 (online) http://jssidoi.org/jesi/

2021 Volume 8 Number 3 (March)

http://doi.org/10.9770/jesi.2021.8.3(34)

Dr. Leszek BOROWIEC is a doctor of economics at the Faculty of Management and Finance of the Academy of Economics and Human Sciencees in Warsaw. Scientific interests: controlling, management accounting, modern cost accounting systems, financial management. He specializes in controlling and cost management in public services.

ORCID ID: orcid.org/0000-0002-6113-9191

Make your research more visible, join the Twitter account of ENTREPRENEURSHIP AND SUSTAINABILITY ISSUES: @Entrepr69728810

Copyright (C) 2021 by author(s) and VsI Entrepreneurship and Sustainability Center

This work is licensed under the Creative Commons Attribution International License (CC BY).

http://creativecommons.org/licenses/by/4.0/

c) (i) Open Access 